\title{
PENGARUH SISTEM OLAH TANAH DAN APLIKASI MULSA BAGAS TERHADAP RESPIRASI TANAH PADA LAHAN PERTANAMAN TEBU (Saccharum officinarum L.) PT GUNUNG MADU PLANTATIONS
}

\author{
Budi Cahyono, Sri Yusnaini, Ainin Niswati \& Muhajir Utomo \\ Jurusan Agroteknologi, Fakultas Pertanian Universitas Lampung \\ Jl.Prof. Soemantri Brodjonegoro, No.1, Bandar Lampung 35145 \\ E-mail:budicahyono146@ymail.com
}

\begin{abstract}
ABSTRAK
Respirasi tanah merupakan suatu proses yang terjadi karena adanya kehidupan mikroorganisme yang melakukan aktifitas hidup dan berkembang biak dalam suatu masa tanah. Respirasi tanah yang mencerminkan tingkat aktivitas mikroorganisme tanah dapat digunakan sebagai salah satu indikator dari pengaruh sistem perawatan yang dilakukan terhadap lahan pertanaman tebu di PT Gunung Madu Plantations (PT GMP). Penelitian ini dilaksanakan pada bulan April sampai Juli 2012 pada lahan pertanaman tebu di PT GMP. Penelitian ini dirancang secara split plot dalam rancangan acak kelompok (RAK) dengan 5 kali ulangan. Petak utama yaitu sistem olah tanah yang terdiri dari dari tanpa olah tanah $\left(\mathrm{T}_{0}\right)$ dan olah tanah intensif $\left(\mathrm{T}_{1}\right)$. Anak petak adalah aplikasi mulsa bagas, yang terdiri dari tanpa mulsa bagas $\left(\mathbf{M}_{0}\right)$ dan mulsa bagas $80 \mathrm{tha}^{-1}\left(\mathbf{M}_{1}\right)$. Hasil penelitian menunjukkan bahwa sistem olah tanah dan aplikasi mulsa bagas tidak memberikan pengaruh yang nyata terhadap respirasi tanah pada saat tanaman tebu berumur 9 bulan dan 12 bulan setelah perlakuan (BSP). Berdasarkan uji korelasi menunjukkan bahwa respirasi tanah tidak mempunyai korelasi dengan $\mathrm{C}$-organik tanah, $\mathrm{pH}$ tanah, suhu tanah dan kelembaban tanah .
\end{abstract}

Kata kunci: mulsa bagas, respirasi tanah, Saccharum officinarum L., sistem olah tanah.

\section{PENDAHULUAN}

Tebu (Saccharum officinarum L.) merupakan tanaman penting sebagai penghasil gula dan lebih dari setengah produksi gula berasal dari tebu. Gula merupakan salah satu kebutuhan pokok bagi penduduk Indonesia. Salah satu perkebunan gula yang ada di Lampung adalah PT Gunung Madu Plantations (PT GMP). Pemanfaatan lahan secara intensif di perkebunan tebu akan berpengaruh pada kondisi lahan. Pengelolaan tanah yang terlalu sering akan mengakibatkan menguatnya pengoksidasian bahan organik. Selain berakibat pada penurunan bahan organik terjadi juga penurunan ruang pori tanah karena hancurnya agregat tanah yang terbentuk sebelumnya (Soepardi, 1983). Salah satu usaha untuk mempertahankan kesuburan tanah bagi pertumbuhan tanaman adalah penambahan bahan organik.Pemberian bahan organik ke tanah akan berpengaruh baik pada sifat fisik, biologi dan kimia tanah. Pada agroindustri gula, pengolahan tebu menjadi gula menghasilkan hasil samping berupa ampas (bagas), blotong, abu ketel dan serasah. Hasil samping tersebut memiliki potensi besar sebagai sumber bahan organik. Selama ini teknik pengelolaan lahan yang telah dilakukan di PT GMP adalah pengolahan tanah secara intensif, meskipun pekerjaan mengolah tanah secara teratur dianggap penting dalam budidaya tanaman, tetapi pengolahan tanah secara intensif dapat menyebabkan terjadinya degradasi tanah.

Respirasi tanah merupakan suatu proses yang terjadi karena adanya kehidupan mikroorganisme yang melakukan aktivitas hidup dan berkembang biak dalam suatu masa tanah. Mikroorganisme dalam setiap aktivitasnya membutuhkan $\mathrm{O}_{2}$ atau mengeluarkan $\mathrm{CO}_{2}$ yang dijadikan dasar untuk pengukuran respirasi tanah. Pengukuran respirasi tanah lebih mencerminkan aktivitas metabolik mikroorganisme daripada jumlah, tipe, atau perkembangan mikroorganisme tanah (Ragil, 2009).

Respirasi tanah yang mencerminkan tingkat aktivitas mikroorganisme tanah dapat digunakan sebagai salah satu indikator dari kesuburan tanah pada lahan pertanaman tebu di PT GMP. Masalahnya apakah berbagai sistem pertanaman yang diterapkan PT GMP tersebut dapat mempengaruhi respirasi tanah yang dapat menggambarkan kesuburan tanah PT GMP.

Penelitian ini bertujuan untuk (1) mengetahui dan mempelajari pengaruh sistem olah tanah terhadap respirasi tanah, (2) mengetahui dan mempelajari pengaruh pengaplikasian mulsa bagas terhadap respirasi tanah, serta (3) mengetahui dan mempelajari interaksi antara sistem olah tanah dan aplikasi mulsa bagas terhadap respirasi tanah. 


\section{BAHAN DAN METODE}

Penelitian ini dilaksanakan pada bulan April sampai Juli 2012 pada lahan pertanaman tebu di PT Gunung Madu Plantations (PT GMP), Lampung Tengah. Analisis contoh tanah dilakukan di Laboratorium Ilmu Tanah, Fakultas Pertanian, Universitas Lampung.

Penelitian ini dirancang dalam rancangan acak kelompok (RAK) dengan pola split plot yang diulang sebanyak 5 kali ulangan. Petak utama yaitu sistem olah tanah yang terdiri dari dari tanpa olah tanah $\left(\mathrm{T}_{0}\right)$ dan olah tanah intensif $\left(\mathrm{T}_{1}\right)$. Anak petak adalah aplikasi mulsa bagas, yang terdiri dari tanpa mulsa bagas $\left(\mathrm{M}_{0}\right)$ dan mulsa bagas $80 \mathrm{t} \mathrm{ha}^{-1}\left(\mathrm{M}_{1}\right)$. Dengan demikian terbentuk 4 kombinasi perlakuan. Adapun kombinasi perlakuan yang diterapkan adalah $\mathrm{T}_{0} \mathrm{M}_{0}$ (tanpa olah tanah + tanpa mulsa bagas), $\mathrm{T}_{0} \mathrm{M}_{1}$ (tanpa olah tanah + mulsa bagas $\left.80 \mathrm{tha}^{-1}\right), \mathrm{T}_{1} \mathrm{M}_{0}$ (olah tanah intensif + tanpa mulsa bagas), $\mathrm{T}_{1} \mathrm{M}_{1}$ (olah tanah intensif + mulsa bagas $80 \mathrm{t} \mathrm{ha}^{-1}$ )

Data yang diperoleh dianalisis dengan sidik ragam pada taraf $1 \%$ dan $5 \%$, yang sebelumnya telah diuji homogenitas ragamnya dengan uji Bartlett dan aditivitasnya dengan uji Tukey. Rata-rata nilai tengah diuji dengan uji BNT pada taraf $1 \%$ dan $5 \%$. Untuk mengetahui hubungan antara respirasi tanah dengan Corganik tanah, $\mathrm{pH}$ tanah, kelembaban tanah, dan suhu tanah akan dilakukan uji korelasi.

Pada petak olah tanah intensif (OTI), tanah diolah sesuai dengan sistem pengolahan tanah yang diterapkan di PT GMP yaitu sebanyak 3 kali pengolahan, yaitu yang pertama menggunakan bajak piringan yang berfungsi mencacah tunggul tebu, memecah dan membalikkan tanah. Pengolahan tanah kedua tetap menggunakan bajak piringan, tetapi arah kerjanya tegak lurus dengan pengelolaan tanah pertama, berfungsi untuk menghaluskan tanah dan sekaligus untuk menyacah ulang tunggul tebu. Pengolahan tanah yang ketiga menggunakan bajak singkal yang berfungsi untuk membalikkan tanah bawahan ke atas dan sekaligus memecahkan lapisan kedap air sehingga mendapatkan tanah yang mampu mendukung perkembangan akar tanaman. Aplikasi BBA sebanyak $80 \mathrm{t} \mathrm{ha}^{-1}$ dilakukan pada saat pengelolaan tanah yang kedua, yaitu dicampur atau diaduk dengan tanah menggunakan traktor. Mulsa bagas diaplikasikan setelah penanaman tebu dengan dosis $80 \mathrm{t} \mathrm{ha}^{-1}$ untuk petak yang diperlakukan dengan mulsa bagas yang diaplikasikan secara manual. Pada petak OTI, gulma dikendalikan secara manual dan sisa tumbuhan gulma dikembalikan ke lahan sebagai mulsa untuk petak yang menggunakan mulsa bagas.
Sedangkan petak yang tidak menggunakan mulsa bagas, sisa tumbuhan gulma dibuang dari petak percobaan.

Pada petak tanpa olah tanah (TOT), tanah tidak diolah sama sekali. Campuran bagas, blotong, dan abu (BBA) diaplikasikan dengan cara ditebar di permukaan dengan dosis $80 \mathrm{t} \mathrm{ha}^{-1}$ bersamaan pada saat aplikasi BBA pada petak OTI. Untuk plot yang diaplikasikan mulsa, mulsa bagas diaplikasikan setelah tebu ditanam dengan dosis $80 \mathrm{t} \mathrm{ha}^{-1}$. Sama seperti petak OTI, gulma pada petak TOT dikendalikan secara manual dan sisa tumbuhan gulma dikembalikan ke lahan sebagai mulsa untuk petak yang tidak menggunakan mulsa bagas. Sedangkan untuk petak yang tidak menggunakan mulsa bagas, sisa tumbuhan gulma dibuang dari petak percobaan.

Analisis C-organik (metode Walkley and Black) dan $\mathrm{pH}$ tanah (dengan perbandingan 1:2,5) dilaksanakan di Laboratorium Ilmu Tanah Universitas Lampung, sedangkan kelembaban tanah dan suhu tanah dilakukan di lokasi percobaan pada saat pengamatan dengan menggunakan alat soil moisture tester dan termometer tanah.

Pengukuran respirasi tanah (metode Verstrate) (Anas, 1986) dilakukan dengan menutup permukaan tanah menggunakan toples yang didalamnya telah diberikan botol film yang berisi $10 \mathrm{ml} \mathrm{KOH} 0,1 \mathrm{~N}$. Untuk kontrol dilakukan hal yang sama, tetapi permukaan tanah ditutup dengan plastik sehingga $\mathrm{KOH}$ tidak dapat menangkap $\mathrm{CO}_{2}$ yang keluar dari tanah. Pengambilan sampel respirasi tanah dilakukan diantara baris tanaman tebu. Agar tidak terjadi kebocoran, toples dibenamkan ke dalam tanah $2-3 \mathrm{~cm}$. Pengukuran ini dilakukan selama 2 jam.

Setelah pengukuran di lapangan selesai, $\mathrm{KOH}$ hasil pengukuran dititrasi di laboratorium untuk menentukan kuantitas $\mathrm{C}-\mathrm{CO}_{2}$ yang dihasilkan. Titrasi dilakukan dengan cara memindahkan $\mathrm{KOH}$ hasil pengukuran ke dalam gelas erlenmeyer dan ditambahkan 2 tetes fenolptalin, sehingga warna berubah menjadi merah muda dan kemudian dititrasi dengan $\mathrm{HCl}$ sampai warna merah muda hilang (larutan berwarna bening), volume $\mathrm{HCl}$ yang diperlukan dicatat. Kemudian ke dalam larutan ditambahkan 2 tetes metil orange sehingga larutan berwarna orange, dan larutan dititrasi kembali dengan $\mathrm{HCl}$ hingga warna orange berubah menjadi warna merah muda. $\mathrm{HCl}$ yang digunakan berhubungan langsung dengan jumlah $\mathrm{CO}_{2}$ yang difiksasi. Pada kontrol juga dilakukan hal yang sama. Jumlah $\mathrm{CO}_{2}$ dihitung dengan mengunakan formula:

$$
C-\mathrm{CO}_{2}=\frac{(a-b) \times t \times 12}{T \times \pi \times r^{2}} \mathrm{C}-\mathrm{CO}_{2}=\frac{(a-b) \times t \times 12}{T \times \pi \times r^{2}}
$$


dengan $\mathrm{C}-\mathrm{CO}_{2}=\mathrm{mg} \mathrm{jam}^{-1} \mathrm{~m}^{-2}, \mathrm{a}=\mathrm{ml} \mathrm{HCl} \mathrm{untuk} \mathrm{contoh}$ tanah, (setelah ditambahkan metil orange), $b=\mathrm{ml} \mathrm{HCl}$ untuk kontrol, (setelah ditambahkan metil orange), $\mathrm{t}=$ normalitas $\mathrm{HCl}, \mathrm{T}=$ waktu pengukuran (jam), dan $\mathrm{r}=$ jari-jari tabung toples.

Variabel pendukung yang diamati adalah C-organik (metode Walkley \& Black), $\mathrm{pH}$ tanah dengan perbandingan $1: 2,5$, suhu tanah, dan kelembaban tanah.

\section{HASIL DAN PEMBAHASAN}

Hasil analisis ragam respirasi tanah dengan sistem olah tanah dan aplikasi mulsa bagas dapat dilihat pada Tabel 1. Dari hasil ringkasan analisis ragam menunjukkan bahwa sistem olah tanah dan aplikasi mulsa bagas tidak memberikan pengaruh yang nyata terhadap respirasi tanah pada saat tanaman tebu berumur 9 dan 12 bulan setelah perlakuan (BSP).

Respirasi tanah merupakan cerminan populasi dan aktivitas mikroorganisme di dalam tanah. Tingkat respirasi tanah sering dihubungkan dengan populasi mikroorganisme tanah. Beragamnya jenis mikroorganisme tanah hanya mungkin ditemukan pada tanah yang mempunyai sifat yang memungkinkan bagi mikroorganisme tersebut untuk berkembang dan aktif. Semakin banyak karbondioksida yang dikeluarkan tanah, semakin tinggi respirasi tanah (Ahmad, 1993 dalam Widayanti, 2010).

Hasil ringkasan analisis ragam (Tabel 1) menunjukkan bahwa sistem olah tanah dan aplikasi mulsa bagas tidak memberikan pengaruh yang nyata terhadap respirasi tanah pada saat tanaman tebu berumur 9 bulan dan 12 bulan setelah perlakuan (BSP). Hal ini diduga karena lahan pertanaman tebu telah dilakukan perlakuan pengolahan tanah 2 tahun sebelum pengamatan respirasi tanah. Hal ini menyebabkan tanah pada areal pertanaman tebu menjadi padat, sehingga ruang pori pada lahan yang dilakukan pengolahan tanah secara intensif maupun tanpa olah tanah menjadi lebih sempit. Keadaan ini mengakibatkan aerasi tanah pada sistem olah tanah intensif maupun tanpa olah tanah menjadi rendah (Utomo, 1990), sehingga sirkulasi udara pada lahan tersebut tidak bebas. Akibatnya, pasokan oksigen dari udara ke tanah menjadi rendah akibatnya aktivitas mikroorganisme dalam merombak bahan organik yang menghasilkan $\mathrm{CO}_{2}$ menjadi rendah.

Menurut Indra Djati (2011), respirasi tanah tertinggi terjadi pada pengamatan pertama (masa vegetatif) yaitu sebesar 7,45 kg hari-1 $\mathrm{ha}^{-1}$, pada pengamatan kedua respirasi tanah menurun menjadi sebesar 7,26 kg hari ${ }^{-1} \mathrm{ha}^{-1}$, dan pada pengamatan ketiga produksi respirasi tanah semakin menurun menjadi 3,69 $\mathrm{kg}$ hari $^{-1} \mathrm{ha}^{-1}$. Hal ini terjadi karena lahan yang baru saja diolah akan menghasilkan respirasi tanah yang tinggi, dan seiring dengan bertambahnya waktu respirasi tanah akan semakin menurun.

Pada Tabel 1 juga menunjukkan bahwa pemberian mulsa bagas tidak berpengaruh nyata terhadap respirasi tanah. Hal ini diduga karena $\mathrm{C} / \mathrm{N}$ rasio mulsa bagas yang sangat tinggi yaitu 86 (Sucipto, 2011) menyebabkan mulsa bagas belum terdekomposisi (terombak) secara keseluruhan. Hal ini sejalan dengan penelitian Dermiyati (1997), yang melaporkan bahwa pemberian serasah tanaman dalam bentuk serasah kedelai, kacang tanah, jerami padi, dan alang-alang dalam kurun waktu 3 bulan tidak berpengaruh nyata terhadap kandungan C-mik tanah. Begitu juga dengan penelitian Suwardjo (1981), aplikasi serasah tanaman berupa serasah kacang tanah, jerami padi, dan jerami jagung selama 4 bulan belum menunjukkan pengaruh yang nyata terhadap kandungan bahan organik tanah, namun setelah satu tahun aplikasi serasah tanaman menunjukkan perbedaan pengaruh terhadap kandungan bahan organik. Proses perombakan bahan organik di dalam tanah sangat dipengaruhi oleh kadar $\mathrm{C} / \mathrm{N}$ dari bahan organik tersebut. Bahan organik berkualitas rendah ( $\mathrm{C} / \mathrm{N}$ tinggi, $>25$ kandungan $\mathrm{N}$ kurang dari $2 \%)$ melepaskan unsur hara secara lambat, sedangkan bahan organik berkualitas tinggi $(\mathrm{C} / \mathrm{N}<25$ kandungan $\mathrm{N}$ lebih dari 2\%) cepat melepaskan unsur hara (Sarno, 2003). Handayanto (1998), menyatakan meskipun bahan organik berkualitas tinggi lambat dalam melepaskan unsur hara, namun dalam jangka panjang bahan organik tersebut akan berguna dalam mempertahankan

Tabel 1. Ringkasan analisis ragam respirasi tanah $\left(\mathrm{mg} \mathrm{jam}^{-1} \mathrm{~m}^{-2}\right)$ saat tanaman tebu berumur 9 dan $12 \mathrm{BSP}$

\begin{tabular}{lcc}
\hline \multirow{2}{*}{ Sumber Keragaman } & \multicolumn{2}{c}{ Waktu Pengamatan } \\
\cline { 2 - 3 } & 9 BSP & 12 BSP \\
\hline Olah tanah (PU) & tn & tn \\
Mulsa (AP) & tn & tn \\
Interaksi & tn & tn \\
\hline
\end{tabular}

Keterangan: $\mathrm{tn}=$ tidak nyata, $\mathrm{PU}=$ petak utama, $\mathrm{AP}=$ anak petak 
kandungan bahan organik tanah dan perbaikan sifat fisik tanah lainnya.

Gambar 1 menunjukkan bahwa respirasi tanah pada saat tanaman tebu berumur 9 BSP lebih tinggi jika dibandingkan dengan tanaman tebu berumur $12 \mathrm{BSP}$. Pada saat tanaman tebu berumur $9 \mathrm{BSP}$ produksi $\mathrm{CO}_{2}$ pada perlakuan tanpa olah tanah tidak diberi mulsa (T0M0) dan tanpa olah tanah diberi mulsa (T0M1) berturut-turut sebesar $30,4 \mathrm{mg} \mathrm{jam}^{-1} \mathrm{~m}^{-2}$ dan $20,3 \mathrm{mg}$ $\mathrm{jam}^{-1} \mathrm{~m}^{-2}$, sedangkan produksi $\mathrm{CO}_{2}$ pada perlakuan olah tanah intensif tanpa mulsa (T1M0) dan olah tanah intensif diberi mulsa (T1M1) berturut-turut sebesar 20,3 $\mathrm{mg} \mathrm{jam}{ }^{-1} \mathrm{~m}^{-2}$ dan $18,7 \mathrm{mg} \mathrm{jam}^{-1} \mathrm{~m}^{-2}$. Pada saat tanaman tebu berumur 12 BSP produksi $\mathrm{CO}_{2}$ pada perlakuan tanpa olah tanah tidak diberi mulsa (TOM0) dan tanpa olah tanah diberi mulsa (T0M1) berturut-turut sebesar $12,8 \mathrm{mg} \mathrm{jam}^{-1} \mathrm{~m}^{-2}$ dan $16,9 \mathrm{mg} \mathrm{jam}^{-1} \mathrm{~m}^{-2}$, sedangkan produksi $\mathrm{CO}_{2}$ pada perlakuan olah tanah intensif tanpa mulsa (T1M0) dan olah tanah intensif diberi mulsa (T1M1) berturut-turut sebesar $10,8 \mathrm{mg} \mathrm{jam}^{-1} \mathrm{~m}^{-2}$ dan $10,5 \mathrm{mg} \mathrm{jam}^{-1} \mathrm{~m}^{-2}$. Jika hasil penelitian ini dibandingkan dengan penelitian pada tanaman jagung Indra Djati (2011), rata-rata emisi gas $\mathrm{CO}_{2}$ yang dikeluarkan perhari pada sistem olah tanah intensif sebesar $6,14 \mathrm{~kg}$ hari $^{-1}$ ha $^{-1}$, sedangkan pada sistem tanpa olah tanah konservasi sebesar 4,97 kg hari-1 $\mathrm{ha}^{-1}$. Maka, produksi respirasi tanah pada tanaman tebu tidak berbeda jauh dengan respirasi tanah pada tanaman jagung.

Ringkasan uji korelasi antara respirasi tanah dengan C-organik tanah, $\mathrm{pH}$ tanah, suhu tanah, dan kelembaban tanah dapat dilihat pada Tabel 2. Hasil ringkasan uji korelasi (Tabel 2) menunjukkan bahwa perlakuan sistem olah tanah dan aplikasi mulsa bagas tidak menunjukkan korelasi terhadap kadar C-organik, pH tanah, suhu tanah, dan kelembaban tanah. Artinya tinggi rendahnya respirasi tanah pada penelitian ini tidak tergantung pada C-organik tanah, $\mathrm{pH}$ tanah, suhu tanah dan kelembaban tanah.

Belum berpengaruhnya mulsa bagas terhadap Corganik, $\mathrm{pH}$, suhu, dan kelembaban tanah di duga karena kandungan $\mathrm{C} / \mathrm{N}$ rasio bagas yang sangat tinggi $\mathrm{C} / \mathrm{N} 86$ (Sucipto, 2011). Disamping itu, waktu penelitian yang

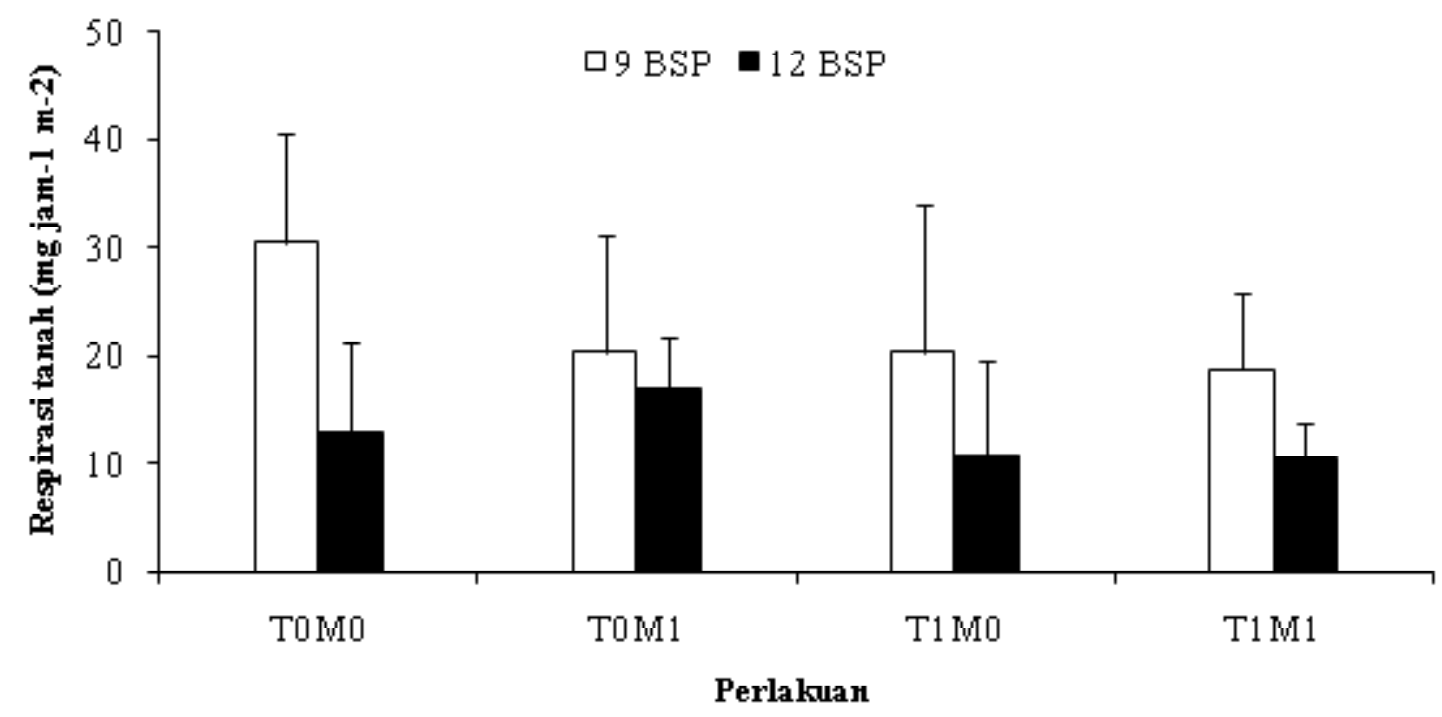

Gambar 1. Respirasi tanah pada lahan pertanaman tebu pada saat tanaman tebu berumur 9 dan 12 bulan setelah perlakuan. $\mathrm{T}_{0} \mathrm{M}_{0}$ (tanpa olah tanah+tanpa mulsa bagas), $\mathrm{T}_{0} \mathrm{M}_{1}$ (tanpa olah tanah+mulsa bagas $80 \mathrm{t} \mathrm{ha}^{-1}$ ), $\mathrm{T}_{1} \mathrm{M}_{0}$ (olah tanah intensif+tanpa mulsa bagas), $\mathrm{T}_{1} \mathrm{M}_{1}$ (olah tanah intensif+mulsa bagas $80 \mathrm{t} \mathrm{ha}^{-1}$ ).

Tabel 2. Ringkasan uji korelasi antara respirasi tanah dengan C-organik tanah, $\mathrm{pH}$ tanah, suhu tanah, dan kelembaban tanah pada saat tanaman tebu berumur 9 dan 12 BSP

\begin{tabular}{lcccc}
\hline Respirasi tanah & C-organik & $\mathrm{pH}$ & Suhu & Kelembaban \\
\hline 9 B SP & $-0,26^{\text {tn }}$ & $-0,03^{\text {tn }}$ & $-0,43^{\text {tn }}$ & $0,26^{\text {tn }}$ \\
12 BSP & $-0,03^{\text {tn }}$ & $0,25^{\text {th }}$ & $0,22^{\text {tn }}$ & $0,25^{\text {n }}$ \\
\hline
\end{tabular}

Keterangan: $\operatorname{tn}=$ tidak nyata. 
baru berjalan 2 tahun membuat mulsa bagas belum terdekomposisi (terombak) secara keseluruhan menjadi C-organik tanah dan unsur hara lainnya, karena waktu yang dibutuhkan untuk pembentukan C-organik tanah cukup lama. Sarno (2003), menyatakan bahwa pemberian bahan organik berkualitas rendah (C/N 25) ke dalam tanah akan melepaskan unsur hara secara lambat.

Utomo (1995), menerangkan bahwa pengaruh perlakuan sistem olah tanah terhadap beberapa sifat tanah seperti C-mik, N-mik, C-organik dan N total baru terlihat setelah beberapa tahun. Hal ini diperkuat dengan hasil penelitian dalam Makalew (2001), yang melaporkan bahwa setelah 16 tahun, penerapan sistem TOT baru memberikan jumlah C-organik (pada permukaan $5 \mathrm{~cm}$ ) yang lebih banyak dibandingkan pada lahan yang diolah.

\section{KESIMPULAN}

Berdasar hasil penelitian dapat disimpulkan bahwa sistem olah tanah pada pertanaman tebu tidak mempengaruhi respirasi tanah saat tanaman tebu berumur 9 dan 12 bulan setelah perlakuan. Aplikasi mulsa bagas pada pertanaman tebu tidak mempengaruhi respirasi tanah pada saat tanaman berumur 9 dan 12 bulan setelah perlakuan. Tidak terdapat interaksi antara sistem olah tanah dan pemberian mulsa bagas terhadap respirasi tanah.

\section{DAFTAR PUSTAKA}

Anas, I. 1989. Biologi Tanah dalam Praktek. Pusat Antar Universitas Bioteknologi. Bogor.

Dermiyati. 1997. Pengaruh Mulsa terhadap Aktivitas Mikroorganisme Tanah dan Produksi Jagung Hibrida C-1. J. Tanah Trop.5:63-68.

Handayanto, E. 1998. Pengelolaan Kesuburan Tanah Secara Biologi untuk Menuju Sistem Pertanian Sustainabel. Habitat (10) 104:1-8.
Indra, D.W. 2011. Pengaruh Sistem Olah Tanah terhadap C-Organik dan Respirasi Tanah pada Pertanaman Jagung di Lahan Petani Lampung. Skripsi. Unila. Bandar Lampung.

Makalew, A.D.N. 2001. Keanekaragaman Biota Tanah pada Agroekosistem Tanpa Olah Tanah (TOT). Makalah falsafah Sains. IPB. 19 hlm.

Ragil. 2009. http://cahtanah.blogspot.com. Diakses tanggal 12 Januari 2011.

Sarno, S. Yusnaini, Dermiyati, dan M. Utomo. 2003. Pengaruh Sistem Olah Tanah dan Pemupukan Nitrogen Jangka Panjang terhadap Kandungan Asam Humik dan Fulfik. J. Tanah Trop.7:35-42.

Soepardi, G. 1983. Sifat dan Ciri Tanah. Faperta-IPB. Bogor. $591 \mathrm{hlm}$.

Sucipto. 2011. Pengaruh Sistem Olah Tanah dan Aplikasi Mulsa Bagas terhadap Kandungan Biomassa Karbon Mikroorganisme Tanah. Skripsi. Universitas Lampung. Bandar Lampung.

Suwardjo, H. 1981. Peranan Sisa-sisa Tanaman dalam Konservasi Tanah dan Air pada Usaha Tani Tanaman Semusim. Disertasi. Sekolah Pasca Sarjana. Institut Pertanian Bogor. Bogor.

Utomo, M. 1995. Reorientasi Kebijakan Sistem Olah Tanah. Prosid. Sem. Nas-V. BDP-OTK. Bandar Lampung. Hal.1-7.

Utomo, M. 1990. Budidaya Pertanian Tanpa Olah Tanah,Teknologi untuk Pertanian Berkelanjutan. Direktorat Produksi Padi dan Palawija, Departemen Pertanian. Jakarta.

Widayanti, A. 2010. Respirasi Tanah Gambut yang diberi Amelioran pada Pertanaman Jagung (Zea mays L.). Skripsi. Fakultas Pertanian. Universitas Lampung. Bandar Lampung. $65 \mathrm{hlm}$. 